excitation (at the Department of Pharmacology, University College, London); Dr. D. E. Green, to continue his studies on intracellular enzymes and on the influence of vitamin B on oxidation processes (at the Institute of Biochemistry, Cambridge); Dr. M. Jowett, to continue his study of the action of narcotic drugs on the metabolism of the central nervous system (at the Biochemical Laboratory, Cardiff City Mental Hospital).

Junior Fellowships (normal value $£ 400$ a year) : I. A. Anderson, for research on iron analyses of diets of women of the poorer classes at Aberdeen, and studies on the treatment of anæmia (at the Metabolic Research Laboratory, Aberdeen Royal Infirmary); Dr. D. Beall, for work on sterol metabolism, with special reference to sex hormones (at the Department of Pathology, British Postgraduate Medical School, London); J. G. Chalmers, for work on the role of polycyclic hydrocarbons in experimental tumour production (at the Glasgow Royal Cancer Hospital); Dr. F. C. Courtice, to study the influence of insulin and endocrine secretions on the metabolism of prolonged muscular exercise (at the Physiology Laboratory, Oxford); H. Davson, to study the cause of primary chronic glaucoma of the eye) at the Department of Physiology and Biochemistry, University College, London; Dr. T. R. R. Mann, for research on intracellular compounds of blood pigment and the metabolism of oxalic acid in mammalian tissue (at the Molteno Institute, Cambridge); Dr. Antoinette Pirie, to study the metabolism of filterable organisms by analysis of their enzyme systems (at the Institute of Biochemistry, Cambridge); Dr. D. Richter, for work on the action of adrenaline and related substances on the metabolism of individual organs (at the Institute of Biochemistry, Cambridge).

\section{Travelling Fellowships in Tuberculosis}

The Medical Research Council has awarded Dorothy Temple Cross research fellowships to the following, who intend to study problems of tuberculosis at centres abroad, during the academic year 1937-38 : Dr. B. C. Thompson, formerly assistant tuberculosis officer, Durham County Council (renewal of present fellowship for three months); R. H. R. Belsey, resident surgical officer, Hospital for Consumption and Diseases of the Chest, Brompton, London; Dr. B. M. Maxwell, senior assistant medical officer, Cheshire Joint Sanatorium, Market Drayton ; 0. S. Tubbs, chief assistant to a Surgical Unit, St. Bartholomew's Hospital, London; Dr. Enid M. Williams, assistant lecturer in tuberculosis, Welsh National School of Medicine, Cardiff.

\section{British Empire Cancer Campaign}

THE quarterly meeting of the Grand Council of the British Empire Cancer Campaign was held on July 12. On the recommendation of the Scientific Advisory Committee, the following grants were approved: $£ 500$ to Dr. P. M. F. Bishop, at Guy's Hospital, for the expenses for one year of certain investigations in regard to endocrine therapy in relation to cancer; $£ 250$ to Prof. G. I. Finch, at the Imperial College of
Science and Technology, for the expenses of an investigation, on behalf of the Scientific Advisory Committee, into the nature and structure of carcinogenic compounds ; and $£ 160$ to Dr. P. R. Peacock, at the Glasgow Royal Cancer Hospital, for the purchase of special apparatus for the continuation of his cancer research. On the recommendation of the Joint Committee of the Campaign and of Mount Vernon Hospital, Dr. G. Cranston Fairchild was reappointed the William Morris research fellow in radiology at that Hospital for a further period of one year. The William Morris research fellowship was established five years ago by a generous donation of a capital sum of $£ 25,000$ by Lord Nuffield.

\section{Occultations of Mars and Venus}

If the evening sky is clear on July 17, an interesting observation can be made without a telescope (though, preferably, slight optical aid is desirable) of the occultation of the planet Mars by the moon. The disappearance of Mars, as seen from a station near Greenwich, takes place at the moon's dark limb (the age of the moon being $9 \cdot 7$ days) at position angle $53^{\circ}$ from the north point of the disk, measured eastwards, at $21^{\mathrm{h}} 13^{\mathrm{m}}$ U.T. $\left(22^{\mathrm{h}} \mathrm{I} 3^{\mathrm{m}}\right.$ Summer Time). The reappearance of Mars at the moon's bright limb is at position angle $326^{\circ}$ at $22^{\mathrm{h}} 10^{\mathrm{m}}$ U.T. or $23^{\mathrm{h}} 10^{\mathrm{m}}$ Summer Time. The apparent diameter of Mars is about $14^{\prime \prime}$ and its stellar magnitude $-0 \cdot 8$. A map in the B.A.A. Handbook for 1937 gives the limits on the earth's surface of the visibility of this occultation. The occultation of Venus by the moon on August 3 takes place in full daylight and cannot, in any event, be seen from southern England. The southern limit of visibility of partial occultation, as given in J. Brit. Ast. Assoc., March, p. 187, runs approximately between Hull, Bradford and a little north of Blackpool; the southern limit of total occultation runs from just south of Bridlington, to Borough Bridge and just north of Carnforth. At Edinburgh, the disappearance of Venus is due at $8^{\mathrm{h}} 26^{\mathrm{m}}$ U.T. at position angle $159^{\circ}$ from the north point of the moon's disk, and the reappearance at position angle $212^{\circ}$ at $9^{\mathrm{h}} 1^{\mathrm{m}}$ (add $1^{\mathrm{h}}$ to convert to Summer Time). The phenomenon will require telescopic aid generally, though Venus can on occasions be 'picked up' in daylight by keen-sighted observers. The moon's age is 26.2 days, so that the crescent is a very narrow one. Venus is in its gibbous phase, the ratio of the illuminated area of the disk to that of the entire apparent disk (17" in diameter) being $0 \cdot 67$. Its stellar magnitude is $-3 \cdot 6$. The position of Venus on August 3 at $9^{\text {h }}$ is R.A. $5^{\mathrm{h}} 53^{\mathrm{m}} \cdot 0 ;$ Dec. $+21^{\circ} 20^{\prime}$.

\section{A New Comet (I937 f)}

A NEW comet was discovered on July 4 not far from the star, $\beta$ Persei (Algol), by Mr. Finsler at Zurich. At discovery, the comet was diffuse without a central condensation of nucleus, but two days later, according to an observation made at Barcelona, a nucleus was observed as well as a short tail somewhat more than $1^{\circ}$ in length. The International 
Astronomical Union Circular No. 664 from Copenhagen gives elements of the comet derived from observations made at several observatories from July 4 to July 7 . Independent elements of the comet's orbit are derived by Möller (Copenhagen), Kwiek (Poznań) and Cunningham (Harvard). These elements give the time of perihelion passage, respectively, as August 12.435, 11.139 and 14.52 U.T. The ephemeris derived from Möller's elements gives the position of the comet at $0^{\mathrm{h}}$ U.T. on July 14, 18 and 22 as follows :

\begin{tabular}{|c|c|c|}
\hline & R.A. & N Decl. \\
\hline July 14 & $3^{\mathrm{b}} \quad 17 \cdot 5^{\mathrm{m}}$ & $45^{\circ} 43^{\prime}$ \\
\hline 18 & $3^{\mathrm{h}} 25 \cdot 6^{\mathrm{m}}$ & $49^{\circ} \quad 59^{\prime}$ \\
\hline 22 & $3^{\text {h }} \quad 39 \cdot 1^{\mathrm{m}}$ & $55^{\circ} 31^{\prime}$ \\
\hline
\end{tabular}

Dr. Steavenson has already observed this comet, which promises to be an interesting object. Its present magnitude is 7 , but the decrease in its present heliocentric and geocentric distances, 1.05 and 1.25 units respectively, will probably cause a considerable increase in brightness.

\section{Announcements}

The first award of the Johannes Schmidt Medal has been made to Mr. Henry G. Maurice, fisheries secretary of the Ministry of Agriculture and Fisheries, and president of the International Council for the Exploration of the Sea, in recognition of his great services to international oceanographical and fisheries research. Most appropriately the presentation, by H.R.H. Prince Waldemar of Denmark, was made in the new offices of the Council in Charlottenlund Slot, on the occasion of the thirteenth annual meeting of the Council, which was held on July 5-10.

IN connexion with the centenary celebrations of the University of Athens (see Nature, May 1, p. 749), the honorary degree of doctor of science was conferred upon Sir Napier Shaw, formerly director of the Meteorological Office and honorary president of the Commission for the Exploration of the Upper Air.

The following officers have been elected to the Council for the year 1937-38 of the Institution of Electrical Engineers: President, Sir George Lee; Vice-Presidents, Sir Noel Ashbridge, Mr. J. R. Beard : Hon. Treasurer, Mr. W. McClelland.

The following, among others, were granted Civil List pensions during the year ended March 31, 1937 : Mrs. Jessie Bennett, in recognition of the services rendered by her husband, the late Mr. Arthur Bennett, to botanical science $(£ 60)$; Dr. Maurice Copisarow, in recognition of his services to science, and in particular to chemical research $(£ 130) ;$ Mrs. Elizabeth MacKenzie, in recognition of the services rendered by her husband, the late Mr. Donald MacKenzie, to the study of anthropology, mythology and folk-lore $(£ 70)$.

THE following appointments have recently been made in the Colonial Service: R. A. Wright, veterinary officer, Malaya; R. J. A. W. Lever (entomologist, British Solomon Islands Protectorate), entomologist, Fiji ; C. Swabey (assistant conservator of forests, Trinidad), forestry officer, Jamaica ; K. J. Johnston (superintendent of surveys), assistant surveyor general, Ceylon; A. V. Lawes (surveyor, Tanganyika), surveyor, Gold Coast; H. M. W. Nicholson (assistant pharmacist), pharmacist, medical department, Tanganyika; H. F. Rainsford (staff surveyor, Tanganyika), computer, survey department, Uganda; W. F. Wegener (assistant chief mechanical engineer), chief mechanical engineer, Federated Malay States Railways; W. W. Williams (assistant superintendent), superintendent of surveys, Ceylon; L. G. O. Woodhouse (assistant surveyor general), deputy surveyor general, Ceylon.

Prof. Paul Montel, professor of the theory of functions and theory of variability at the Sorbonne, has been elected a member of the Section of Geometry of the Paris Academy of Sciences, in succession to the late Prof. E. Goursat.

M. LÉon Guillet, director of the École Centrale des Arts et Manufactures, and professor at the Conservatoire des Arts et Métiers, Paris, has been nominated an honorary vice-president of the Iron and Steel Institute.

Profs. Jules Bordet, director of the Pasteur Institute of Brussels, and Pierre Nolf, president of the Red Cross, have been awarded the Grand Cross of the Order of Leopold.

Dr. Rufus Cole, director of the Hospital of the Rockefeller Institute for Medical Research since 1909, has retired. His successor is Dr. Thomas Milton Rivers, who has been a member of the board of scientific directors of the International Health Division of the Rockefeller Foundation since 1927.

The Paul Appel Prize and Gold Medal of the Renaissance française, for the best contribution in recent years to the campaign against social scourges, has been awarded to the French League against. Cancer for the "Index Analyticus Cancerologicus", commenced eleven years ago under the scientific direction of MM, Forgue, de Nobile, Hartmann, Rogard and Roussy. The recipients of the prize are MM. Lacassagne and Lavedan, general secretaries of the League.

A "Catalogue of Books and Journals on Zoology, Biology and Geology" (No. 507) for sale by W. Heffer and Sons, Ltd., Cambridge, contains 1,886 items. General works and scientific journals are well repre. sented, as also are the groups dealing with entomology, ornithology and geology.

Is connexion with the notes on national and international standardization in NATURE of July 3, p. 19, we are asked to state the Survey to which they refer can be obtained from the Central Office of the World Power Conference, 36 Kingsway, London, W.C.2, price $3 s$. $6 d$., or $3 s$. $8 d$. post paid; copies may also be ordered through any bookseller. 